\title{
A Probe into the Postmodernism in The French Lieutenant's Women
}

\author{
Zhang Minglan \\ Foreign Language College, Huaiyin Institute of Technology, 223001, Jiangsu, China \\ 894899157@qq.com
}

\section{Keywords: postmodernism, The French Lieutenant's Woman, Victorian Age}

\begin{abstract}
The French Lieutenant's Woman is generally regarded as one of the classic postmodernist novels. This paper attempts to analyze the postmodern writing techniques in The French Lieutenant's Woman : the first is the narrator's intervention, who dissects the characters, plots and so on; the second is alternative endings that complement and deconstruct one another; the third is self-revealed characteristics, which is reflected in the exposure of and mediation upon the creative process and fiction of the novel;the fourth is uncertainty of the character, particularly the characterization of the protagonist Sarah. The postmodern writing techniques in this novel helps reconstruct and deconstruct the Victorian society.
\end{abstract}

\section{Introduction}

John Fowles was an English novelist, much influenced by both Sartre and Camus, and critically positioned between modernism and postmodernism. Although Fowles did not identify himself as an existentialist, his writing was motivated by a feeling that the world was absurd. Fowles was named by the Times as one of the 50 greatest British writers since 1945.

John Fowles was a prolific author and most of his books are in print today, among them the most hailed is The French Lieutenant's Woman. In 1968, he moved to Lyme Regis in Dorset, and where he lived in Belmont House, also used as a setting for parts of The French Lieutenant's Woman. The French Lieutenant's Woman earned Fowles the Silver Pen Award. ${ }^{[1]}$ Due to its artistic merit and contemporary significance, The French Lieutenant's Woman was made into a film in 1981 with a script by the British scriptwriter Harold Pinter and was nominated for an Oscar.

The French Lieutenant's Woman is generally regarded as the classic novel of postmodernism. But what is postmodernism? The term "postmodernism" originated among artists and critics in New York in the 1960s. And it was advocated by European theorists in the 1970s. Postmodern theory was identified with the critique of universal knowledge and foundation. Among the central features associated with postmodernism are: the deletion of the boundary between art and everyday life; a shift of emphasis from content to form or style; a transformation of reality into images. There are other references to quotation, parody, fragmentation and allegory. Moreover, with the development of postmodernism in recent years, there has been a move to textualize everything: history, philosophy and other disciplines are treated as so many optional "kinds of writing" or discourse. ${ }^{[2] 35}$

This paper interprets postmodernism from the aspects of postmodern narrative characteristics in the novel, including the narrator's intervention, alternative ending, self-revealed characteristics and uncertainty of the character, which are worth further exploring so as to reflect the ossification of traditional literature mode, what's more, to dig aesthetics thoughtful literary mode that caters for modern people.

\section{Postmodern Narrative Techniques in The French Lieutenant's Woman}

\subsection{The Narrator's Intervention}

From the macro aspect, The French Lieutenant's Woman is a 1960s account of nineteenth-century events. Almost two decades elapsed between the release of the novel. Such a span in time is particularly meaningful in light of the novel's treatment of temporality. However, the narrator, to a 
degree, stands for a era. The narrator's intervention such as his twentieth-century perspective on the nineteenth-century narrative is bound to bring the elements of his era to another era.

Of the three young women who pass through these pages Mary was, in my opinion, by far the prettiest. She had infinitely the most life, and infinitely the least selfishness; and physical charms to match ... an exquisitely pure, if pink complexion, corn-colored hair and delectably wide gray-blue eyes, eyes that invited male provocation and returned it as gaily as it was given. ${ }^{[3] 75}$

And numerous temporal allusions are packed into this short excerpt. For example, contemporary beauty criteria are contrasted with those from the Victorian Age. These aspects stress the evanescence of time, whether in the passing of generations, in the time elapsed during the writing of a novel, or in the evolution of beauty canons.

The narrator openly asserts and comments on the power that the novelist has over his narrative's temporality:You may think novelists always have fixed plans to which they work, so that the future predicted by Chapter One is always inexorably the actuality of Chapter Thirteen. But novelists write for countless different reasons: for money, for fame, for reviewers, for parents, for friends, for loved ones; for vanity, for pride, for curiosity, for amusement: as skilled furniture makers enjoy making furniture, as drunkards like drinking, as judges like judging, as Sicilians like emptying a shotgun into an enemy's back. ${ }^{[3] 96}$

Fowles' fictional power enables him to recreate the past and to toy with the future of his characters. He may change his mind and deviate from the future he predicted at the onset of the novel. In doing so, he creates a world that ignores the boundaries of past, present, and future, which is only limited by the confines of the narrator's imagination. In addition, his continually shifting perspectives on historical time (nineteenth /twentieth century), place (Lyme/London, England/Europe/United States), and classes (aristocracy,bourgeois/working class), as well as on gender, invert the text to a multiplicity of voices and perspectives.

From the micro aspect, the narrator's intervention has an effect on the characters' identity. Fowles' novel presents a narrator with a broader view, the telescopist of the opening scene, who ironically comments upon Charles' limited point of view. Besides, due to the narrator's intervention, shifting between the narrative and the narrator's commentary, the novel's oppositional structure thus functions to subvert a privileged process of reading both in Charles's relationship to Sarah and in the reader's relationship to the text.

\subsection{Alternative Ending}

Another remarkable characteristic in The French Lieutenant's Woman is alternative ending. In The French Lieutenant's Woman, there is no closure of discourses. The author subtly weaves three alternative endings for our readers to choose.The three endings are located at various places in the novel and imply different meanings. In the first, Charles ignores Sarah's invitation to Endicott's Family Hotel and returns directly to Lyme: he marries Ernestina and eventually enters her father's business. In the second, having broken with Ernestina, he rediscovers Sarah, finds that she is the mother of his child, and is reunited with her. In the third, he again rediscovers Sarah, but she rejects him, and he is left abandoned and alone. The three endings show the three directions in which Charles could evolve from his dawning existentialist anxiety of freedom. The first ending presented in Chapter 43-44 is to reject freedom, to yield to his conformist self, to return to Ernestina and to creep back into the closed Victorian ideology. This is obviously not a possibility if the novelist is to allow his characters their freedom. The second ending presented in Chapter 60, in which Charles is reunited with Sarah and becomes a second response to the anxiety of freedom. Charles, having rejected conforming and obedience to social convention, chooses the figure who has consciously personified freedom from convention to the extent of being a social outcast. It might be thought that this represents an answer which the narrator could support. Although he does not explicitly direct us how to treat it, as he did in the case of the earlier ending, there are a number of implicit pointers as to how it should be read. It is, in short, another kind of wish fulfillment, the triumph of the Victorian romantic side of Charles' personality. All these endings comprise Fowles' challenge to the closed endings of 
classic realism. Throughout his novel, Fowles rejects totalized, single, and determined narratives, and advocates openness and pluralism.

\subsection{Self-revealed Technique}

Fowles' novel repeatedly subverts the readers' attempt to focus on the represented narrative and encourages them to pay more attention to the processes of creating and reading the narrative. Thus, readers play a role in supervising creation. The novel thus engages the reader in questioning the process of reading and analyzing the conceptual and psychological dynamics by which we construct not only texts but also self. As Charles finally must accept his inability to apprehend Sarah, the reader becomes aware of a textual resistance to appropriation. Fowles' novel requires that the readers forego narrative closure and the authoritative reading in pursuit of a larger significance - the pursuit of insight and freedom. The freedom, as the narrator reminds us, allows other freedoms to exist. Freedom is bound to challenge authority. The most striking issue that emerges from chapter 13 is related to the question of authority in the novel:The novelist is still a god, since he creates (and not even the most aleatory avant-garde modern novel has managed to extirpate its author completely); what has changed is that we are no longer the gods of the Victorian image, omniscient and decreeing; but in the new theological image, with free-dom our first principle, not authority. ${ }^{[3] 97}$

Nonetheless, as the narrator suggests, the godlike third person narrator fails to give freedom to his characters, and makes up the main reason for utilizing the ironic first-person narrator. Part of the irony of the first-person narrators is related to the fact that while he often stresses his innocence and gives freedom to his characters, he continues to dominate them. However, fortunately, Fowles makes it.

Actually, the relation between fiction and reality is indeed a usual novelistic concern. While Fowles creates a real world for characters and readers, he breaks down this situation without hesitation:Perhaps you suppose that a novelist has only to pull the right strings and his puppets will behave in a lifelike manner; and produce on request a thorough analysis of their motives and intentions. Certainly I intended at this stage to tell all-or all that matters. ${ }^{\text {[3]95 }}$

Realistic writers find it important to create an imitation as objectively as possible. Being the mirror of life, fiction is treated as stable object and restricted structure in correspondence to the orderly real world. Modernist fiction responded to the initial loss of belief in such a world.

\subsection{Uncertainty of the Character}

Owing to the title The French Lieutenant's Woman, the protagonist is easily located. However, after reading the novel, readers are puzzled at the question:"Who is Sarah?” The question also arises out of a semantically undecidable passage through the narrator's voice. In this novel, Charles is jolted out of his vaguely uneasy complacency by the mysterious Sarah Woodruff, whom he attempts to interpret as a riddle. Then the reader is positioned, like Charles, to apprehend the mysterious woman.

At first, Charles views Sarah as a woman with two adverse qualities. On the one hand, Charles views her as part of nature, Eve in the Garden of Eden, and is fascinated by "a wildness about her", her hair, her eyes. Charles' sexual attraction to Sarah involves this marginality, her position at the very limits of the cultural and the symbolic order, neither known nor unknown. Charles first sees Sarah at the limits of the rampart. He comes upon her again in the undercliff, that densely wooded wild place at the edge of town, which will bring forth the underside of the self he presents to society. However, within the narrative, she is identified as both whore and virgin, both intelligent and insane. When Charles sees her, at times he is reminded of foreign prostitutes, at other times, visions of the Madonna. He is, on occasion, magnetically drawn to her difference; on other occasions, repelled and fearful. In brief, he is most fearful when aware of her difference.

When Charles, his uncertain perceptions and feelings regarding Sarah, turns to Dr. Grogan, the reader hears the patriarchal voice of reason, science, and the law dialogue. Charles thought he is able to cure Sarah. But Dr. Grogan declares that Charles is unable to reason and examine her motives so that he can not understand why she behaves as she does. One must see her as a being in a mist. All they can do is to wait and hope that the mists disappear. 
After they make love and then the conditions of their relationship become evident, Charles charges that he has been no more than the dupe of his imaginings. Charles comes to view Sarah as the embodiment of the marginal, a symbol marking the site of resistance to the stifling Victorian society.

Sarah is unavailable to readers physically or mentally. Readers are constantly seeing Sarah but the descriptions of her appearance are ambiguous and uncertain. And in all the most dramatic scenes between Charles and Sarah, the descriptions of her actions are peppered with the ambiguous phrase "as if " and words such as "seems" and "almost". These descriptive ambiguities can of course support the idea that Sarah has actually planned what, to Charles, appears to happen by chance.

In the novel, Sarah has identified herself, and allowed the community to identify her, and even leads readers to identify her as the French lieutenant's woman. This position has often been interpreted as the stance of a free woman. But as Fowles has pointed out, she too is determined by history. The name identifies her in relation to a male, the position of any young woman in Victorian patriarchal culture, for it would be accorded identity through the father or husband. As the French lieutenant's woman, Sarah deliberately casts herself in the marginal position assigned to woman, declaring that she exists "beyond the pale”. And as an outcast, she exists at the edge of patriarchal rule. Sarah's identity is not authentic, but she does accurately name her position. Charles believes that he is choosing a marginal existence with Sarah, and he dreams of dressing her and subsuming her subjectivity and pulling her back into the center. It turns out a daydream. When comes to the ending of this novel, it turns out that much of the information Sarah at first offers about herself is, like the other readings of her, lies. Consequently, readers' knowledge about Sarah is almost zero because a "New Woman" should be evaluated through new view, and is no longer "the French lieutenant's woman".

The French Lieutenant's Woman is generally regarded as a historical novel which presents a panorama of the Victorian Age. History is the supporting or explanatory background. There is no doubt that historical knowledge of the Victorian era will surely provide us with a better understanding about this novel. The novel's narrative is historicized through its evocation of a particular period in the past, with detailed representation from all classes and real personages such as Marx, Darwin and the Victorian poets whose texts are often quoted. Here Fowles recontextualizes, reconstructs what these historical figures had already written about the Victorian world. Just as Fowles' novel is all imagination, so the accounts of such writers, especially the poets, are also imaginary. The novel is also historicized through the deployment of historical documents to us in a textualized and narrativized form ${ }^{[4]}$

\section{Conclusion}

In concluding this paper, this paper emphasizes the entire narrative structure of the novel. As critics said, each story of Fowles tells the same story, that is, the story of the survival of individual freedom, including the free place the author provides for readers. In the first place, Fowles is interested in endings as he agrees that life offers an infinity of possible endings. The three endings in The French Lieutenant's Woman offer freedom to the author, to the characters, and to the readers. Besides, Fowles uses different tenses within this work because he prefers to set the nineteenth and twentieth centuries against each other and describes the novel as a science fiction journey back in time. Moreover, Like most postmodernists, Fowles is self-consciously eager to admit that story he has created is out of imagination. Last but not the least, Fowles selects a riddle as a protagonist. It is ridiculous that no one knows who Sarah is. Therefore, there are more room for others to understand and interpret the character.

\section{References}

[1] Fowles, John. Notes on Writing a Novel [ J]. Harper’s Magazine, 1968( 237): 161.

[2] Zim, Peter V. The Philosophy of Modern Literary Theory[M]. London: The Athlone Press, 1999. 
[3] Fowles, John. The French Lieutenant's Woman[M]. Xi'an: World Publishing Corporation, 1997.

[4] Lodge, David. Working with Structuralism: Essays and Reviews on $19^{\text {th }}$ and $20^{\text {th }}$ Literature[ M ]. Boston: Routledge and Kegan Paul, 1981: 99. 